\title{
Handan Karakaya, Türkiye'de Dindar Burjuva ve Kadın (Religious Bourgeois and Women in Turkey), İstanbul: Kaknüs Yayınları, 2017, 428 s.
}

Kübra Yıldırım Demiroğlu*

Handan Karakaya'nın 2017'de Kaknüs Yayınları'ndan çıkan Türkiye'de Dindar Burjuva ve Kadın adlı eseri kendisinin doktora çalışmasıdır. Karakaya'nın çalışmasının konusunu Türkiye'de ekonomik ve sosyal alanlarda hayat standartları değişen muhafazakâr dindar kesimin hayatı, dini algılama biçimlerinin nasıl değiştiği ve kadınların bu değişim üzerindeki rolü oluşturmaktadır.

Çalışma "Burjuva Kavramı ve Burjuvanın Gelişimi”, "Osmanlı İmparatorluğu: İktisadi Yapı, Batılılaşma ve Burjuva Sınıfi", "Türkiye'de Burjuvanın Yeni Yaşam Pratikleri ve Kadın” olmak üzere üç ana bölümden oluşmaktadır. Eserin birinci ve ikinci bölümlerinde burjuva kavramı, Osmanlı'da burjuva sınıfının ortaya çıkışı ve gelişimi, Osmanlı iktisadi yapısı, Batılılaşma ve burjuva sınıfı konularından bahsedilmiştir. Eserin başlığında vurgulanan dindar burjuva ve kadın konusu ise eserin üçüncü bölümünde yer almaktadır.

Kitabın birinci bölümünde Handan Karakaya, burjuvazinin Avrupa'da ortaya çıkışından ve tarihsel serüveninden bahseder. Karakaya, burjuvazi teriminin toplum içerisinde üretim, tüketim, dağıtım, ithalat, ihracat gibi kavramlar çerçevesinde yeni yaşam pratiklerinin önderleri olarak tanımlanabileceğini ve toplum içinde küçük bir grup olarak başlayan burjuvazinin zaman içerisinde kendine ait değer ve kültür oluşturarak Avrupa toplumlarını sosyal, ekonomik bağlamlarda dönüştürdüğünü ifade eder. Yazar, Doğu toplumlarında ise -Avrupa ülkeleriyle siyasi, sosyal ve dinî farklılıklardan

* Marmara Üniversitesi İlahiyat Fakültesi Din Sosyolojisi Yüksek Lisans öğrencisi,kubrayyildirim@gmail.com 
dolayı- burjuvanın Avrupa'da yarattığı etki ve dönüşümün gerçekleşmediğini, bu toplumların Batı'yı yalnızca izlemekle yetindiğini söyler. Bu durumu Doğu toplumlarının burjuva zihniyetine sahip olmamasıyla açıklar.

Karakaya, Osmanlı toplumları ve özelinde Türk toplumunda İslam dininin ihtiyacından fazlasını tüketmeyi tavsiye etmemesi, ticaret erbabının para kazanmayı ve biriktirmeyi ömrünü geçirecek değer olarak görmeyip bunları yermesi, devletin siyasi dengeyi bozacak bir burjuva sınıfına hoş bakmaması Osmanlı Devleti'nde keskin sosyal sınıfların oluşmamasına sebep olduğunu anlatır. Osmanlı'nın ardindan Cumhuriyet rejiminde ise toplumun siyasi, ekonomik pek çok sorunuyla baş edebilmek ve toplum üzerinde sınırlı bir etki alanı oluşturabilmek için milli burjuva sınıfı oluşturulmaya çalışıldığını ancak bu burjuva sınıfının diğer burjuva sinıflarından devlete bağımlılığı bakımından ayrıldığını ifade eder.

Eserin ikinci bölümünde Karakaya, Osmanlı iktisadi yapısı, Batılılaşma ve burjuva sınıfı konularına odaklanır. Bu bölüme, Türkiye Cumhuriyeti kurulduktan sonra yaşanan siyasi gelişmelerin kronolojisiyle söze başlayan Karakaya, 1946-50 döneminde Demokrat Parti'nin kurulmasıyla daha önceki yıllarda modernleşme ve Batılılaşmayla geri plana atılmak istenen dinin kamusal hayatta yeniden yeşermeye başladığını söyler. Bu bağlamda 1980 sonrasında Anavatan Partisi'yle seçimleri kazanan Turgut Özal'la taşra burjuvası aralarında örgütlenerek Müstakil Sanayici ve İş Adamları Derneği'ni (MÜSİAD) kurmuş, yabancı yatırımcılarla yeni ilişkiler geliştirmiştir. Karakaya Özal'ın girişimleriyle atağa geçen taşralı muhafazakâr kesimin yurt dışında eğitim alarak devletin kilit kademelerinde rol almalarını yeni muhafazakâr elitlerin ilk basamağı ve yeni muhafazakâr burjuvanın ilk nüveleri olarak değerlendirir.

Yazara göre 2002 genel seçimlerinde iktidara gelen Adalet ve Kalkınma Partisi dönemine gelindiğinde, sahnede artık kendine özgü bir burjuva sınıfı vardır. Karakaya yeni yükselen bu muhafazakâr burjuvanın ve onların iktidara taşıdığı AK Parti'nin temel felsefesinin başlangıçta "bir lokma, bir hırka" ifadesiyle dünya nimetlerine 
minnet etmeyen bir anlayışta olduğunu ancak bu durumun zamanla ticaretin ve para kazanmanın Hz. Peygamber tarafindan özendirildiği anlayışına evrildiğine dikkat çeker.

Karakaya, Anadolu sermayesinin desteğiyle iktidara gelen AK Parti'nin 28 Şubat döneminde ezilmiş, pek çok insanî hakkı elinden alınmış, haksızlığa uğramış orta sınıfın "rövanşist hissiyatının tatmin edilmesi” gibi bir görev yüklendiğini ifade eder. Karakaya'nın kullandığ "Rövanşist hissiyat" ifadesi tartışmaya değerdir. Zira pek çok insanın özellikle başörtülü genç kızların bütün hayatını etkileyecek sonuçlarıyla 28 Şubat postmodern darbesi, rövanşı alınamayacak ölçüde büyük acılara sebep olmuş ve binlerce nitelikli genç kızın eğitim ve sonrasında çalışma hakkını elinden almıştır. Dolayısıyla AK Parti Hükûmetiyle elde edilen özgürlükler, hak kaybına uğrayan insanların haklarını iade etmekten öte bir şey gibi gözükmemektedir.

Eserin üçüncü ve son bölümünde Avrupa ve Türk toplumunda kadın olgusunu ele alan Karakaya Avrupa'da XIX. yüzyılda burjuvazi aracılığıyla kadın emeğinin nasıl metalaştığından, kadınların toplumsal hayatta görünürlüklerinin artmasıyla sahip olmaları gereken haklardan mahrum edildiklerinden, dinî normların baskısıyla toplumsal konumlarının erkeklerden daima aşağıda olduğundan ve Avrupa'da olduğu gibi İslam toplumlarında da kadının değerinin olmadığ 1 ve kendisine fitne olarak bakıldığ varlığını örtünerek var ettiğinden bahseder. Ancak İslamî literatüre ve hayat pratiğine bakıldığında Karakaya'nın bu ifadesinin indirgemeci yönü kendini göstermektedir.

Karakaya, Türk toplumunda kadın konusunu ise İslamcı, milliyetçi ve Batıcı aydınlar ekseninde okur. Batıcıların kadınların toplumdaki konumu, peçe ve çarşaf sorunu, kadınların eğitimi gibi konular üzerinde durduklarını; Abdullah Cevdet, Rıza Tevfik gibi yazarların dinî bazı uygulamaları ve örtünmeyi kadınların sosyal alanda var olup kendilerini geliştirmeleri için bir engel olarak gördüklerini belirtir. Yazar, İslamcıların ise dinin kadına Batı dünyasından çok daha fazla haklar verdiğini ancak uygulamadaki bazı hatalardan dolayı kadınların toplumda geri planda kaldığını 
savunduklarını iddia eder. Milliyetçi akımın önde gelen isimlerinden Ziya Gökalp, Halide Edip Adıvar gibi yazarların Türk kadınının Arap ve Bizans etkisinden kurtarılarak eski Türk medeniyetlerinde olduğu gibi erkeklerle eşit statüye sahip olmasını savunduklarını ifade eder.

Osmanlı'da Tanzimat Fermanı'nın ilanıyla pek çok alanda olduğu gibi kadınların sosyal hayata katılmalarında önemli değişiklikler olmuştur. Bu dönemde kadınlar kendilerini ifade edebilecekleri çeşitli dergiler çıkarmış, özellikle şehirli kadınlar giyim kuşamda farklı tarz kıyafetler kullanmaya başlamışlardır. Yine ilk feminist örgüt sayılabilecek olan Teâlî-i Nisvan Cemiyeti bu dönemde kurulmuştur. Cumhuriyet’in ilanıyla Türk kadınına toplumu dönüştürme, modernleştirme misyonu yüklenmiştir. Cumhuriyet'le kadınlar seçme seçilme, çalışma hakkı gibi pek çok hakka sahip olsa da eğer "çağdaş kadın" stereotipine girmemişse; mesela muhafazakâr dindar ve geleneklerine bağlı bir kadınsa toplumda varlığı görmezden gelinmiş ve ötekileştirilmiştir. Bu bağlamda yeni Türk kadınından beklentilerin, onu geleneksel ve dinî değerlere karşı mücadele içine soktuğu söylenebilir.

Karakaya; modernleşmenin, Batı toplumlarında ortaya çıkmasıyla birlikte insan ve toplum üzerinde büyük dönüşümlere sebep olduğunu ve bu dönüşümleri Batı toplumları kendilerini yeniden tanımlama noktasında daha az hasarla atlatılırken Doğu toplumlarında ise sürecin oldukça zor olduğunu ifade eder. Doğu toplumlarında olduğu gibi İslamî değerlere sahip bir toplum olan Türk toplumu içinde modernleşme serüveninin 1980 sonrasına daha sancılı ve çetrefilli olduğundan bahseder.

Yazar, 1980 sonrası dönemde dindar-muhafazakâr kamunun öne çıkan kadın entelektüel ve gazetecilerinden Ayşe Böhürler, Cihan Aktaş, Hidayet Şefkatli Tuksal gibi isimlerle yaptığı mülakatlarla çeşitli dergilerde yayımlanan makalelerinden yola çıkarak 1980 sonrasında başörtülü kadınların kamusal alanda var olma mücadelelerini aktarır. Böhürler, 2014'te kendisiyle yapılan mülakatta 1980'den itibaren Müslüman muhafazakâr genç kızların 
üniversitelerde daha sık görünür olduklarını ve başörtülü genç kızlar içinde bulundukları geleneğin din anlayışına karşı çıkarak Kur'an ve sünnet ekseninde bir din anlayışını benimsediklerinden bahseder. Böhürler'e göre bu durum Müslüman camiadan bir kesimin tepkisine sebep olsa da asıl tepki laik kesimden gelmiş ve tesettür siyasal İslam’a indirgenmiştir.

Karakaya, Aktaş'tan "bacı" kavramının kullanımını başörtülü kadınların mücadelesi için örneklendirir. Aktaş, "bacı" sıfatının Müslüman başörtülü kızlar için evlerinin dışına çıktıklarında geleneksel İslam'a göre fesat sebebi olmamak için büründükleri bir sıfat olarak açıklar. Tuksal ise mülakatında sistemin dışladığı başörtülü kadınların gittikleri üniversitelerde kendi camialarının erkekleri tarafından da dışlandığını ve dindar erkeklerin kadının yerinin evi olduğu algısını aşamadıkları vb. hususlara yer verir. 1990 sonu itibariyle de kamusal alanda başörtüsü yasağı uygulanmış, başörtülü kadınların hem öğrenim hakları hem de çalışma hakları kısıtlanmıştır. Yazara göre bu şekilde kadınların kamusal alandan tecrit edilmesi hem Kemalist ideolojiyi hem de "kadının yerinin evi olduğu" anlayışına sahip olan muhafazakâr camianın bir kısım erkeklerini rahatlatmıştır. Ancak Müslüman dindar kadınlar kamusal alanda var olma mücadelesini değişen siyasi ortamın verdiği imkânlar ölçüsünde gerçekleştirmeye çalışmışlardır.

Karakaya, Fadime Özkan'la 2014 yılında yaptığı mülakata dayanarak Müslüman kadınların değişen tesettür biçimleriyle ve AK Parti iktidarının sağladığı özgürlüklerle kamusal alanda kendilerini ifade edebildiğini, bunu da kapitalist modern yaşamla uyumlu şekilde yaptıklarına değinir. Özkan, 2000'lere gelindiğinde 90'larda oldukça yaygınlaşan ve başörtülü kadınlar arasında da farklılaşmalara sebebiyet veren büyük başörtüsü, uzun pardösülerin yerine ikame edilen yeni bir moda anlayışının oluşmasından bahseder. Bu durumun tesettüründe daha dikkatli ve az dikkatli kadınları aynılaştırdığını da ekler.

Karakaya 2000'li yıllarda muhafazakâr dindar kadınların dinî yaşayışlarının yanı sıra daha modern ve kentli elit kadın olma 
arzusunda olduklarını ifade eder. Bu ifadesini Böhürler'le yaptığı mülakatta başörtülü kadınların AK Parti iktidarıyla eşi başörtülü başbakan ve bakanların ortaya çıkması, resmî protokollerde başörtülülerin yer alması ve dolayısıyla artık kentli, elit kadın profilinin değişmesine dayandırır. Uzun yıllar sindirme politikalarına ve baskılara maruz kalmış Müslüman muhafazakâr kadınların dünyaya açılmaya ve kendilerini yeniden tanımlamaya başladıklarını açıklar.

Karakaya kendini muhafazakâr dindar olarak tanımlayan kadınlarla yaptığı saha çalışmasını oluşturan mülakatlardan hareketle, Müslüman muhafazakâr zengin kadınların lüks tüketim unsurlarını İslamî sembollerle ev dekorasyonlarında ve kıyafetlerinde kullanmalarını; lüks mekânlara gitmeleri, ciplere binmeleri, yatak odalarına üç metrelik palmiyeler almaları, arabalarına gül suyu pompalayan klimalar taktırmaları gibi örneklerle somutlaştırır. Ancak yazarın verdiği bu örneklerin ne ölçüde kapsayıcı olduğu yahut yaygınlığı tartışmaya açık bir husustur. Müslümanların İslam’ı algılama biçimlerinin değişmesinin altını çizen Karakaya, zekât, sadaka, merhamet, infak gibi kavramların muhafazakâr dindar burjuva kadınların lüks harcamalarının yanında sık kullandığı kelimeler olduğunu belirtir. Karakaya, İslamî usullere göre inşa edilen yaşam alanlarını, muhafazakâr dindar burjuva kadınların değişen tüketim ve alışveriş pratiklerini; onların kapitalizmle barışması olarak görür. Ona göre 1980'lerde "Millî Görüş" yahut "İslamcı Hareket" içindekiler yaşam tarzı ve giyim kuşamda olabildiğine sade mütevazı bir görünüme sahipken; peygamber sünnetine dayandırılan bu sadelik yerini muhafazakâr dindar burjuvanın kamusal alanda özgürlükler elde etmesi ve hayat standartlarının yükselmesiyle birlikte Hz. Peygamber'in temiz ve iyi giyinen bir insan olduğu anlayışıla meşrulaşan yeni yaşam tarzlarına bırakmıştır.

Handan Karakaya'nın Türkiye'de Dindar Burjuva ve Kadın adlı eseri, Avrupa ve Türk toplumunda burjuvazinin tarihsel gelişimine mukayeseli olarak yer vermesi, Türk siyasi tarihinin iktisadi yapısına, modernleşme dinamiklerine ışık tutması ve muhafazakâr dindar kadının Türk siyasi tarihinde var olma serüvenini ele alması 
literatür açısından oldukça değerlidir. Eser, çalışmanın başında da belirtildiği gibi üç ana bölümden oluşmaktadır. Ancak kitaba adını veren Türkiye'de Dindar Burjuva ve Kadın konusu eserin yalnızca son bölümünde kitabın hacmine göre oldukça az yer tutacak bir şekilde yer almıştır. Bu durum eser ve başlığı arasında bir uyumsuzluk olduğu kanısına varmaya sebep olmaktadır. Yine çalışma içerisindeki bazı yargıların indirgemeci yahut kalıplaşmış ifadeler olup olmadığı hususu tartışmaya açıktır. Bu olumsuz duruma karşın Türkiye'de Dindar Burjuva ve Kadın konusu muhafazakâr dindar kadınlarla yapılan mülakat, söyleşi, dergi ve köşe yazılarıyla dönemin muhafazakâr dindar kadınlarının tecrübe ve gözlemlerine yer verilmesi açısından kıymetlidir. 